\title{
Pola Interaksi Guru dan Orang Tua dalam Penerapan Pembelajaran Daring
}

\section{Ida Ayu Putu Nandri Pratiwi ${ }^{*}$, Luh Ayu Tirtayani²}

1,2 Prodi Pendidikan Anak Usia Dini, Universitas Pendidikan Ganesha, Singaraja, Indonesia

\section{A R T I C L E I N F O}

\section{Article history:}

Received July 31, 2021

Revised August 03, 2021

Accepted November 26, 2021

Available online December 25, 2021

Kata Kunci:

Pola Interaksi, Guru, Orangtua

Keywords:

Interaction Patterns, Teachers, Parents

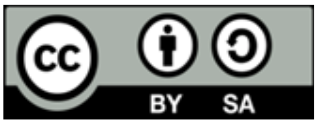

This is an open access article under the CC BY-SA license.

Copyright () 2021 by Author. Published by Universitas Pendidikan Ganesha.

\begin{abstract}
A B S T R A K
Adanya pandemi COVID-19 menyebabkan pembelajaran dilaksanakan secara daring, hal ini menimbulkan permasalahan yaitu kurangnya pemahaman siswa akan proses pembelajaran daring dilihat dari kondisi siswa yang masih tergolong anak usia dini yang kesulitan untuk memahami pembelajaran sehingga dibutuhkan peran orangtua untuk memantau kegiatan anak dalam pelaksanaan pembelajaran daring. Maka dari itu, perlu diketahui bagaimana penerapan pola interaksi guru dan orang tua dalam pelaksanaan pembelajaran secara daring. Penelitian ini bertujuan untuk mendeskripsikan pola interaksi guru dan orang tua dalam penerapan pembelajaran secara daring. Jenis penelitian yang digunakan dalam penelitian ini adalah penelitian survei deskriptif dengan pendekatan kuantitatif. Subjek penelitian ini sebanyak 83 guru dari total populasi sebanyak 103 guru. Pengumpulan data dalam penelitian ini menggunakan metode non tes dengan intrumen berupa kuesioner tertutup. Tahapan analisis data dalam penelitian ini menggunakan persentase data mean (rata-rata). Hasil penelitian ini dilihat dari aspek interaksi kontak sosial menunjukkan hubungan guru dan orangtua dalam pembelajaran daring termasuk dalam kriteria yang positif dan dari aspek interaksi komunikasi menunjukkan hubungan guru dan orangtua dalam pembelajaran daring juga termasuk dalam kriteria yang positif. Maka, dapat disimpulkan bahwa dalam pelaksanaan pembelajaran daring pola interaksi guru dan orangtua sudah terjalin dengan baik. Implikasi dari penelitian ini yaitu hasil penelitian ini dapat digunakan sebagai refrensi terkait dengan penerapan pola interaksi guru dan orangtua siswa dalam pelaksanaan pembelajaran daring.
\end{abstract}

\section{A BS TRACT}

The existence of the COVID-19 pandemic has caused learning to be carried out online, this raises problem is the less of understanding of students in online learning processes that seen from the condition of students who are still classified as early childhood who have difficulty understanding learning, so that the role of parents is needed to monitor children's activities in the implementation of online learning. So, it is necessary to know how to apply the interaction patterns of teachers and parents in the implementation of online learning. This study aims to determine the interaction patterns of teachers and parents in the application of online learning. The type of research used in this research is descriptive survey research with a quantitative approach. The subject of this study was 83 teachers from a total population of 103 teachers. Data collection in this study used a non-test method with the instrument in the form of a closed questionnaire. The stages of data analysis in this study used the percentage of the mean (average) data. The results of this study, seen from the aspect of social contact interaction, showed that the relationship between teachers and parents in online learning was included in the positive criteria and from the aspect of communication interaction showed the relationship between teachers and parents in online learning was also included in the positive criteria. So, it can be concluded that in the implementation of online learning the interaction pattern of teachers and parents has been well established. The implication of this research is that the results of this study can be used as a reference related to the application of teacher-parent interaction patterns in the implementation of online learning. 


\section{PENDAHULUAN}

Adanya wabah Covid-19 menyebabkan kegiatan pembelajaran yang awalnya dilakukan secara tatap muka dialihkan menjadi pembelajaran dalam jaringan (daring/online) dengan konsep belajar dari rumah (BDR). Hal ini tertuang dalam surat edaran oleh kementerian pendidikan dan kebudayaan (Kemendikbud) nomor 4 tahun 2020 tentang pelaksanaan kebijakan pendidikan dalam masa darurat penyebaran COVID-19 yang memuat tentang proses belajar dari rumah melalui pembelajaran daring atau pembelajaran jarak jauh guna untuk tetap memberikan pengalaman belajar yang bermakna bagi siswa, dengan difokuskan pada pemberian pendidikan mengenai kecakapan hidup terkait Covid-19 (Arifa, 2020; Astini, 2020; Dewi, 2020). Pembelajaran daring atau dalam jaringan sudah dikenal oleh masyarakat, pembelajaran daring ini menjadi solusi pembelajaran di masa pandemi COVID-19. Pembelajaran daring merupakan sebuah inovasi pendidikan yang menggunakan sistem pembelajaran dengan tidak melakukan pembelajaran tatap muka langsung, tetapi melibatkan unsur teknologi informasi dalam pembelelajaran melalui platform/aplikasi virtual yang tersedia meskipun dilakukan dengan jarak jauh (Fitriyani et al., 2020; Handarini \& Wulandari, 2020; Syarifudin, 2020). Dalam pelaksanaan pembelajaran daring dapat memanfaatkan berbagai macam jenis aplikasi seperti zoom, google class room, Whatsapp, google meet dan aplikasi lainnya serta dapat menggunakan beberapa jenis media lain seperti media cetak, audio, video, radio ataupun televisi (Astuti \& Presiadi, 2020; Kristina et al., 2020). Sehingga dengan adanya pembelajaran daring ini mengaharuskan semua lembaga pendidikan tidak terkecuali lembaga pendidikan anak usia dini harus siap untuk melaksanakan pembelajaran daring. Dengan diterapkannya pembelajaran daring dalam masa pandemi diharapkan anak akan tetap bisa belajar dengan efektif dan dapat menyesuaikan proses pembelajaran ini.

Namun, dalam pelaksanaan pembelajaran daring terdapat beberapa permasalahan yang dialami oleh guru dalam pelaksanaan pembelajaran daring seperti kurangnya pemahaman siswa akan alur atau proses pembelajaran daring dilihat dari kondisi peserta didik yang masih tergolong anak usia dini yang kesulitan untuk memahami pembelajaran, ketidaksiapan guru dan peserta didik dalam pelaksanaan pembelajaran daring, dan keterbatasan penggunaan teknlogi, dimana perpindahan sistem belajar ke sistem daring secara tiba-tiba dikarenakan COVID-19 tanpa persiapan yang matang menyebabkan sejumlah guru ada yang tidak mampu mengikuti perubahan dengan pembelajaran berbasisi teknologi sehingga pembelajaran tidak dapat dilaksanan secara efektif dan berpengaruh terhadap perkembangan kompetensi siswa (Aji, 2020; Putro et al., 2020; Suryaman et al., 2020). Hal ini tentunya tidak sejalan dengan konsep pendidikan untuk anak usia dini yaitu belajar sambil bermain, karena anak usia dini merupakan masa golden age (Usia keemasan) yaitu pada masa ini terjadi banyak sekali pertumbuhan dan perkembangan, bahkan masa keunggulan untuk melatih dan mendidik perkembangan anak sehingga pada masa ini anak usia dini yang dikontrol sejak dini akan menghantarkannya pada pencapaian manusia yang sempurna (Ayuni et al., 2020; Mahdi et al., 2020). Selain itu, anak usia dini juga masih perlu bimbingan langsung dan masih memerlukan banyak kegiatan untuk menstimulasi pencapaian perkembangan kognitifnya (Ansari \& Purtell, 2017; Larimore, 2020). Sehingga dalam masa perkembangan anak usia dini diperlukan pengawasan untuk anak dalam melaksanakan pembelajaran. Dengan adanya pembelajaran daring tentunya guru tidak bisa sepenuhnya mengawasi anak pada saat pembelajaran, maka dalam hal ini orangtua juga harus terlibat dalam mengawasi dan membantu anak dalam melaksanakan pembelajaran daring. Untuk itu, maka sangat diperlukan interaksi dan kerjasama antara orang tua dan guru dalam melaksanakan pembelajaran daring.

Pola interaksi merupakan bentuk-bentuk dalam terjadinya aktivitas/proses interaksi. Pola interaksi ialah bentuk-bentuk atau model saat saling melakukan aksi dalam kegiatan pemberian dan penerimaan informasi berdasarkan pada adanya pesan yang akan disampaikan (Koten \& Iswayudi, 2019; Kurniasih, 2020). Jika dikaitkan dalam pelaksanaan pembelajaran pola interaksi guru dan orangtua dapat berupa aktivitas kerjasama dan komunikasi yang dilakukan oleh guru dengan orangtua terkait dengan pelaksanaan pembelajaran. Kerja sama merupakan interaksi yang terjadi ketika ada sekelompok orang yang melakukan kerja secara bersama-sama yang tumbuh dari sebuah komitmen individu untuk mendapat hasil yang baik untuk kepentingan bersama maupun kesejahteraan bersama (Rihatno, 2017; Risdoyok \& Aprison, 2021). Sehingga kerja sama antara orangtua dan guru dapat diartikan sebagai sebuah hubungan antara guru dan orangtua dalam mendidik, memantau dan mengajar anak guna meningkatkan kemampuan anak dalam bidang akademik, sikap maupun keterampilannya. Hubungan guru dan orangtua dilakukan untuk menjalin kebutuhan yang dibutuhkan oleh sekolah dan orangtua itu sendiri, sehingga tercapainya tujuan interaksi guru dan orang tua yakni untuk meningkatkan usaha dalam memenuhi kebutuhan siswa (Cahyati \& Kusumah, 2020; Lilawati, 2020). Dengan adanya interaksi antara guru dan orang tua maka kebutuhan masing-masing pihak akan sangat mudah untuk dipenuhi, apalagi dalam pelaksanaan pembelajaran daring sangat diperlukan kerjasama yang baik antara guru dan orangtua peserta didik agar siswa dapat melaksanakan pembelajaran secara efektif. 
Selain adanya kerjasama antara guru dengan orangtua, diperlukannya juga komunikasi yang efektif antara guru dan orangtua untuk menunjang terlaksananya pembelajaran dengan baik. Komunikasi merupakan penyampaian informasi, dengan adanya komunikasi orang tua dapat memberitahu kepada guru mengenai kondisi anak dan guru bisa memberi informasi terkait perkembangan peserta didik selama proses pembelajaran, dimana secara umum komunikasi antara guru (sekolah) dengan orangtua dapat dibedakan menjadi komunikasi formal dan non formal (Anwas, 2011; Kartini, 2020). Komunikasi guru dan orang tua dalam pemenuhan pertumbuhan pengetahuan anak sangat dibutuhkan dalam membangun belajar anak pada masa pandemi Covid-19, sehingga komunikasi antara guru dan orangtua harus dilakukan secara bersinergi dalam memposisikan pendidikan untuk anak didiknya (Ardiawan \& Heriawan, 2020; Winarti, 2020). Ketika anak melakukan tugasnya sebagai pelajar khususnya pada pembelajaran daring walaupun terhalang oleh jarak tetapi proses belajar mengajar harus tetap berlangsung. Walaupun guru tidak dapat memantau proses belajar secara langsung maka diperlukan kerja sama atau interaksi komunikasi antara guru dengan orang tua agar anak tetap melaksanakan kewajibannya sebagai seorang pelajar. Sehingga di dalam berlangsungnya proses belajar mengajar di masa pandemi saat ini sangat diperlukan interaksi atau hubungan antara guru dengan orang tua dalam memantau penerapan pembelajaran secara daring. Guru dapat memberikan pemahaman ke orang tua dalam penerapan pembelajaran daring dan orang tua juga dapat menerapkan hasil interaksi dengan guru kepada anak. Dengan demikian, kerja sama guru dan orang tua sangat diperlukan supaya anak tetap melaksanakan pembelajaran dengan baik dan tercapainya tujuan pembelajaran. Maka dari itu peneliti tertarik untuk melakukan penelitian berkaitan dengan interaksi antara guru dan orangtua dalam pelaksanaan pembelajaran daring. Adapun penelitian ini bertujuan untuk mendeskripsikan pola interaksi guru dan orang tua dilihat dari aspek interaksi sosial dan komunikasi dalam penerapan pembelajaran secara daring di TK Kecamatan Blahbatuh.

\section{METODE}

Jenis penelitian yang digunakan dalam penelitian ini yakni penelitian survei deskriptif dengan pendekatan kuantitatif. Penelitian ini dilaksanakan di TK yang berada di wilayah Kecamatan Blahbatuh. Populasi dalam penelitian ini yaitu 103 guru TK yang tersebar dalam 20 TK yang ada di Kecamatan Blahbatuh. Pada pelaksanaan penelitian ini, dikarenakan tidak memungkinkan untuk mempelajari keseluruhan populasi maka perlu dipilihnya sampel penelitian untuk mewakili seluruh guru-guru TK yang tersebar di Kecamatan Blahbatuh. Untuk menentukan sampel penelitian digunakan teknik Proportional Random Sampling. Berdasarkan hasil perhitungan yang telah dilakukan dengan tingkat presisi 5\%, maka diperoleh sampel yang mewakili populasi sebanyak 82 guru. Secara lebih rinci pembagian sampel penelitian disajikan pada Tabel 1.

Tabel 1. Sebaran Sampel Penelitian

\begin{tabular}{clccc}
\hline No & & Desa & Populasi & Sampel \\
\hline 1 & Desa Bedulu & 18 & 14 \\
2 & Desa Belega & 4 & 3 \\
4 & Desa Blahbatuh & 7 & 6 \\
5 & Desa Bona & 8 & 6 \\
7 & Desa Buruan & 14 & 11 \\
8 & Desa Keramas & 26 & 21 \\
9 & Desa Pering & 11 & 9 \\
10 & Desa Saba & 15 & 12 \\
\hline & & & $\mathbf{8 2}$ \\
\hline
\end{tabular}

(Sumber: UPT Dikpora Kecamatan Blahbatuh)

Metode pengumpulan data yang digunakan dalam penelitian ini yaitu menggunakan metode nontes dengan jenis penyebaran kuisioner/angket. Instrument yang digunakan dalam penelitian ini yakni menggunakan kusioner dengan jenis kuisioner tertutup. Penyebaran kusioner dilakukan dengan bantuan google form. Kusioner yang disebarkan memuat tentang pola interaksi guru dengan orangtua yang terdiri dari aspek kontak social dan aspek komunikasi. Pemilihan jawaban dari kuisioner yang telah dibuat menggunakan penskoran dengan skala likert yaitu dengan rentang skor 1 sampai dengan 4 . Adapun kisikisi instrumen penelitian pola interaksi guru dengan orangtua disajikan pada Tabel 2. Untuk memastikan kualitas dari instrumen kuisioner yang digunakan memiliki kualitas yang baik dan layak untuk digunakan, maka dilakukan uji validitas instrument dengan melakukan uji kelayakan yaitu uji validitas isi oleh para ahli yang membidangi topik instrumen yang digunakan (judgment experts). Jumlah ahli yang dilibatkan dalam 
melakukan uji kelayakan berjumlah 2 orang sebagai ahli isi. Dari hasil perhitungan validitas isi yang telah dilakukan terhadap 30 butir pernyataan dalam angket pola interaksi guru dan orag tua, diperoleh koefisien validitas isi 1,00 dan termasuk kriteria validitas isi sangat tinggi. Selanjutnya, setelah dilakukan penyebaran kuisioner data yang telah dikumpulkan dianalisis dengan menggunakan metode analisis statistik deskriptif kuantitatif. Metode analisis statistik deskriptif kuantitatif digunakan untuk mengolah data dari hasil penyebaran instrumen penelitian untuk mendapatkan suatu kesimpulan. Data yang dikumpulkan berupa skor hasil penyebaran kusioner, kemudian dianalisis dengan teknik analisis statistik deskriptif yang terdiri dari mnghitung mean dan persentase.

Tabel 2. Kisi-Kisi Instrumen Penelitian Pola Interaksi Guru Dengan Orangtua

\begin{tabular}{|c|c|c|}
\hline $\begin{array}{l}\text { Vari } \\
\text { abel }\end{array}$ & Komponen & Indikator \\
\hline $\begin{array}{l}\text { Inter } \\
\text { aksi } \\
\text { Guru }\end{array}$ & $\begin{array}{c}\text { Kontak } \\
\text { sosial } \\
\text { (social- } \\
\text { contact) }\end{array}$ & $\begin{array}{l}\text { Keterlibatan guru dan orang tua untuk persiapan pembelajaran daring } \\
\text { Penggunaan perantara teknologi aplikasi zoom dalam proses pelaksanaan } \\
\text { pembelajaran } \\
\text { Mengupayakan kesepahaman mengenai pelaksanaan pembelajaran daring } \\
\text { Kerja sama antara guru dan orang tua dalam pelaksanaan belajar mengajar } \\
\text { Kolaborasi guru dan orang tua sangat menetukan pelaksanaan belaja anak } \\
\text { Berkoordinasi dengan sesama guru untuk penyusuan (RPPH) } \\
\text { Saling memahami proses mempersiapkan media dan sumber belajar anak } \\
\text { guru dan orangtua bersama-sama merencanakan untuk menciptakan iklim } \\
\text { belajar yang positif } \\
\text { Keterbukaan guru dan orang tua dalam proses pendampingan belajar } \\
\text { Guru dan orangtua saling mengembangkan empati terkait upaya masing- } \\
\text { masing dalam mendampingi belajar anak } \\
\text { Guru memberikan dukungan dan motivasi kepada orang }\end{array}$ \\
\hline
\end{tabular}

(Sumber: Modifikasi Adha et al., 2019)

\section{HASIL DAN PEMBAHASAN}

Hasil

Deskripsi data yang dipaparkan dalam penelitian ini ialah hasil data mengenai pola interaksi guru dan orangtua dalam penerapan pembelajaran daring pada TK di Kecamatan Blahbatuh. Data yang diperoleh dalam penelitian ini bersumber dari hasil penyebaran kuisioner yang terdiri dari 30 butir pernyataan yang terbagi menjadi 2 (dua) aspek variabel yang diteliti yaitu aspek kontak sosial dan aspek komunikasi dalam penerapan pembelajaran daring. Data pada aspek kontak sosial dari pola interaksi guru dan orangtua dalam penerapan pembelajaran daring diperoleh berdasarkan penyebaran kuisioner yang berjumlah 15 butir pernyataan yang bersumber dari 5 indikator dengan 4 pilihan jawaban dari 82 guru sebagai responden. Adapun hasil dari penyebaran kusioner dalam aspek kontak sosial disajikan pada Tabel 3.

Tabel 3. Hasil Perhitungan Penyebaran Kusioner dalam Aspek Kontak Sosial

\begin{tabular}{lll}
\hline \multicolumn{1}{c}{ Indikator } & Persentase & Keterangan \\
\hline $\begin{array}{l}\text { Keterlibatan guru dan orang tua untuk persiapan pembelajaran daring } \\
\text { Pengunaan aplikasi zoom / whatsapp dalam proses pelaksanaan }\end{array}$ & $82 \%$ & Positif \\
pembelajaran & $85.37 \%$ & $\begin{array}{l}\text { Sangat } \\
\text { Positif }\end{array}$ \\
$\begin{array}{l}\text { Mengupayakan kesamaan mengenai pelaksanaan belajar mengajar } \\
\text { Sangat }\end{array}$ & $85.16 \%$ & $\begin{array}{l}\text { Positif } \\
\text { Kerja sama antara guru dan orang tua dalam pelaksanaan belajar anak } \\
\text { Kolaborasi guru dan orang tua sangat menentukan pelaksanaan belajar }\end{array}$ \\
\hline \multicolumn{1}{c}{ Presentase Rerata Kontak Sosial } & $80.89 \%$ & Positif \\
\hline
\end{tabular}

Berdasarkan Tabel 3. diketahui bahwa hasil perhitungan masing-masing indikator kontak sosial yang pertama yakni keterlibatan guru dan orang tua untuk persiapan pembelajaran memperoleh persentase sebesar $82.22 \%$ dengan kriteria positif. Indikator yang kedua terkait penggunaan aplikasi zoom/whatsapp dalam proses pelaksanaan pembelajaran memperoleh persentase sebesar $85.37 \%$ dengan kriteria sangat positif. Indikator yang ketiga yaitu mengupayakan kesepahaman mengenai pelaksanaan 
belajar mengajar memperoleh persentase sebesar $85.16 \%$ dengan kriteria sangat positif. Selanjutnya, indikator yang keempat yakni kerja sama antara guru dan orang tua dalam pelaksanaan belajar anak memperoleh persentase sebesar $80.89 \%$ dengan kriteria positif. Terakhir, indikator yang kelima terkait kolaborasi guru dan orang tua sangat menentukan pelaksanaan belajar anak memperoleh persentase sebesar $82,22 \%$ dengan kriteria positif. Sehingga, berdasarkan hasil perhitungan seluruh indikator pada komponen kontak sosial diperoleh persentase rerata yaitu sebesar $83.17 \%$ dengan kriteria positif. Maka dari itu, dapat dinyatakan bahwa dalam aspek kontak sosial pada pola interaksi guru dan orangtua dalam pelaksanaan pembelajaran daring yang dilakukan di Kecamatan Blahbatuh termasuk dalam kategori baik. Selanjutnya, data pada aspek komunikasi dari pola interaksi guru dan orangtua dalam penerapan pembelajaran daring diperoleh berdasarkan penyebaran kuisioner yang berjumlah 15 butir pernyataan yang bersumber dari 6 indikator dengan 4 pilihan jawaban dari 82 guru sebagai responden. Adapun hasil dari penyebaran kusioner dalam aspek kontak sosial disajikan pada Tabel 4.

Tabel 4. Hasil Perhitungan Penyebaran Kusioner dalam Aspek Komunikasi

\begin{tabular}{llll}
\hline No & \multicolumn{1}{c}{ Indikator } & Persentase & \multicolumn{1}{c}{ Keterangan } \\
\hline 1 & Berkoordinasi dengan sesama guru untuk menyusun (RPPH) & $85.67 \%$ & Sangat Positif \\
2 & $\begin{array}{l}\text { Saling memahami proses mempersiapkan media dan sumber } \\
\text { belajar anak }\end{array}$ & $82.62 \%$ & Positif \\
& $\begin{array}{l}\text { Guru dan orang tua bersama-sama merencanakan untuk } \\
\text { menciptakan iklim belajar yang positif }\end{array}$ & $84.32 \%$ & Positif \\
& $\begin{array}{l}\text { Keterbukaan guru dan orang tua dalam proses pendampingan } \\
\text { belajar }\end{array}$ & $85.37 \%$ & Sangat Positif \\
& $\begin{array}{l}\text { Guru dan orang tua saling mengembangkan empati terkait } \\
\text { upaya masing-masing dalam mendampingi belajar anak }\end{array}$ & $85.21 \%$ & Sangat Positif \\
6 & Guru memberikan dukungan dan motivasi kepada orang tua & $85.37 \%$ & Sangat Positif \\
\hline \multicolumn{2}{c}{ Presentase Rerata Komunikasi } & $\mathbf{8 4 . 7 6 \%}$ & Positif \\
\hline
\end{tabular}

Berdasarkan Tabel 4. diketahui bahwa hasil perhitungan masing-masing indikator dari aspek komunikasi yang pertama yakni berkoordinasi dengan sesama guru untuk menyusun (RPPH) yang memperoleh persentase sebesar $85,67 \%$ dengan kriteria sangat positif. Indikator yang kedua yaitu saling memahami proses mempersiapkan media dan sumber belajar anak memperoleh persentase sebesar $82,62 \%$ dengan kriteria positif. Indikator yang ketiga yaitu guru dan orang tua bersama-sama merencanakan untuk menciptakan iklim belajar yang positif memperoleh persentase sebesar $84,32 \%$ dengan kriteria positif. Indikator yang keempat yakni keterbukaan guru dan orang tua dalam proses pendampingan belajar memperoleh persentase sebesar $85,37 \%$ dengan kriteria sangat positif. Selanjutnya, indikator yang kelima yaitu guru dan orang tua saling mengembangkan empati terkait upaya masingmasing dalam mendampingi belajar anak memperoleh persentase sebesar $85,21 \%$ dengan kriteria sangat positif. Terakhir, indikator yang keenam yakni guru memberikan dukungan dan motivasi kepada orang tua memperoleh persentase sebesar $85,37 \%$ dengan kriteria sangat positif. Sehingga, berdasarkan hasil perhitungan seluruh indikator pada komponen komunikasi diperoleh persentase rerata yaitu sebesar 83,30\% dengan kriteria positif. Maka dari itu, dapat dinyatakan bahwa dalam aspek komunikasi pada pola interaksi guru dan orangtua dalam pelaksanaan pembelajaran daring yang dilakukan di Kecamatan Blahbatuh termasuk dalam kategori baik.

\section{Pembahasan}

Penelitian yang dilakukan di TK yang ada di Kecamatan Blahbatuh dengan jumlah responden sebanyak 82 orang bertujuan untuk mengindentifikasi pola interaksi guru dan orangtua dalam penerapan pembelajaran daring di TK Kecamatan Blahbatuh yang didasarkan pada teori para ahli maupun peneliti mengenai pola interaksi guru dan orangtua dalam penerapan pembelajaran daring di masa pandemi Covid19 ini. Berdasarkan hasil penelitian yang telah dilakukan diketahui bahwa dalam aspek kontak sosial antara guru dan orangtua dalam penerapan pembelajaran daring di TK termasuk ke dalam kategori baik, begitu juga dengan aspek komunikasi antara guru dan orangtua siswa dalam penerapan pembelajaran daring di TK termasuk ke dalam kategori baik, sehingga secara keseluruhan pola interaksi guru dan orangtua dalam penerapan pembelajaran daring termasuk dalam kategori baik dilihat dari sudah terjalinnya hubungan yang baik antara guru dan orangtua baik dalam aspek kontak sosial dan komunikasi dalam penerapan pembelajaran daring.

Penelitian ini menemukan bahwa pola interaksi guru dan orangtua dalam aspek kontak sosial pada penerapan pembelajaran daring di TK Kecamatan Blahbatuh menunjukkan hasil yang baik terlihat dari guru-guru yang sudah menjalin hubungan yang baik dengan orangtua siswa. Hal ini terbukti dari hasil 
survey yang telah dilakukan dalam aspek kontak sosial menunjukkan bahwa persentase rerata guru dalam melakukan interaksi kontak sosial sebesar $83.17 \%$ yang termasuk dalam kategori baik. Pemerolehan persentase tersebut dikarenakan dari hasil penyebaran kuisioner didapatkan bahwa dalam pelaksanaan pembelajaran daring ini guru-guru di TK Kecamatan Blahbatuh sudah dapat menjalin kerjasama dengan orangtua siswa dengan baik yang dapat dilihat dari sudah adanya keterlibatan dan kolaborasi orangtua dalam pembelajaran daring. Tentunya ini merupakan suatu hal yang baik yang sudah dilakukan oleh guru dengan adanya kerjasama yang baik antara guru dan orangtua peserta didik tentunya akan mendukung pelaksanaan pembelajaran daring. Guru dan orangtua harus saling bekerjasama mengembangkan kemampuan yang dimiliki oleh peserta didik. Apalagi dalam pembelajaran daring ini, guru sudah tidak bisa memantau seluruh aktivitas siswa, sehingga peran orangtua sangat dibutuhkan dalam mengembangkan aktivitas siswa. Kerjasama guru dengan orangtua peserta didik pada pelaksanaan pembelajaran dapat dilaksanan dengan guru yang menyiapkan pembelajaran dan memberikan instruksi dan orangtua yang menjelaskan dan melaksanakan maksud dari instruksi kepada peserta didik, sehingga kolaborasi anatara guru dengan orangtua sangatlah penting karena anak usia dini belum dapat menerima arahan guru dengan jelas akibat kurangnya pengalaman dan pengetahuan terkait pelaksanaan pembelajaran daring (Apriyanti, 2021; Irwanto, 2020). Maka dari itu, keterlibatan orangtua dalam mendampingi anak pada saat pembelajaran daring sangat penting untuk diperhatikan, agar pembelajaran anak tetap dapat terlaksana (Hasanah et al., 2020; Musyarrofah et al., 2021; Rasmitadila et al., 2020). Pada dasarnya guru dan orang tua harus saling membantu dan saling mengerti antara satu sama lainnya karena masing-masing memiliki pengaruh tersendiri bagi peserta didik, sehingga dapat terwujudnya sikap saling mengerti dan bantumembantu antar keduanya (Fauzi \& Sastra Khusuma, 2020; Limbong et al., 2020). Apalagi pada pelaksanaan pembelajaran daring ini keduanya memiliki peran yang sangat penting dalam terlaksananya pembelajaran sehingga tujuan pembelajaran dapat tercapai.

Selain itu, penelitian ini juga menemukan bahwa pola interaksi guru dan orangtua dalam aspek komunikasi pada penerapan pembelajaran daring di TK Kecamatan Blahbatuh menunjukkan hasil yang baik terlihat dari sudah terjalinnya koordinasi yang baik antara guru-guru dengan orangtua siswa. Hal ini terbukti dari hasil survey yang telah dilakukan dalam aspek komunikasi menunjukkan bahwa persentase rerata guru dalam melakukan interaksi komunikasi sebesar $83.30 \%$ yang termasuk dalam kategori baik. Pemerolehan persentase tersebut dikarenakan dari hasil penyebaran kuisioner didapatkan bahwa dalam pelaksanaan pembelajaran daring ini sudah adanya koordinasi yang baik antara guru-guru di TK seKecamatan Blahbatuh dengan orangtua siswa yang dapat dilihat dari sudah adanya keterbukaan antara guru dengan orangtua siswa dalam penerapan pembelajaran daring baik dari segi persiapan pembelajaran sampai pelaksanaan pembelajaran. Guru dan orangtua harus saling menjaga komunikasi yang baik antara satu sama lainnya. Dalam pelaksanaan pembelajaran daring khususnya di TKi komunikasi antara guru dang orangtua dilakukan dengan bertujuan agar dalam hal ini orang tua dapat membantu anak dalam berinteraksi dengan gurunya lewat media sosial, ataupun lewat media pembelajaran online lainnya mengingat usia dari peserta didik di TK belum mencukupi umur untuk menggunakan alat komunikasinya sendiri, guru menjalin komunikasi dan kerjasama dengan orang tua siswa agar orang tua selalu mengingatkan, membantu, dan memberikan bimbingan kepada anaknya agar tetap belajar di rumah (Khadijah \& Gusman, 2020; Sutarto et al., 2020). Pentingnya terjalin komunikasi yang baik antara guru dan orang tua dalam pembelajaran daring ini akan menentukan kesuksesan dari pelaksanaan pembelajaran daring. Keberhasilan pelaksanaan pembelajaran daring akan terlaksana dengan maksimal jika antara guru dan orangtua dapat saling bekerjasama dalam mendidik dan mendampingi anak (Angus, 2020; Chusna \& Utami, 2020; Khadilkar et al., 2020).

Berdasarkan pemaparan tersebut, pola interaksi antara guru dengan orangtua dalam penerapan pembelajaran daring di TK Kecamatan Blahbatuh telah dilaksanakan dengan baik oleh para guru dan juga orangtua peserta didik. Kondisi seperti ini tentunya menjadi salah satu solusi agar anak dapat belajar dengan baik walaupun dilaksanakan dari rumah. Hal ini tidak terlepas dari peran dari guru dan orangtua dalam pembelajaran. Guru dang orangtua harus saling bersinergi untuk menciptakan terbentuknya sikap, pengetahuan, dan keterampilan peserta didik, sebab jika hal ini tidak dapat terjalin dengan baik maka akan menyebabkan sulitnya mengarahkan peserta didik pada pencapaian tujuan pembelajaran, apalagi kondsi wabah yang tidak memungkinkan siswa dapat bertatap muka di kelas menyebabkan guru sangat berusaha untuk memanfaatkan orang tua sebagai mitra untuk melaksanakan pembelajaran anak di rumah, tentu jika tidak ada kerjasama yang baik akan sulit rasanya tercapai tujuan pembelajaran yang diharapkan (Lubis \& Nasution, 2017; Wardati et al., 2020). Dalam kerjasama ini guru berperan dalam menyiapkan materi, sumber belajar, dan membangung komunikasi dengan orangtua sedangkan orangtua berperan mengambil materi pembelajaran hingga memberikan pendampingan bagi peserta didik, hal ini dilakukan agar sekolah dapat terus memantau aktivita belajar peserta didik dari rumah (Diana et al., 2021; Nurasiah \& Solehuddin, 2021). Dengan demikian, sangat diperlukan kerjasama dan komunikasi yang baik antara guru dan orangtua 
peserta didik agar kegiatan pembelajaran daring dapat berjalan dengan baik dan tujuan pembelajaran yang diharapkan dapat tercapai. Kontribusi dari adanya penelitian ini yaitu dapat digunakan sebagai acuan/tolak ukur terkait interaksi yang dilakukan antara guru dengan orangtua peserta didik dalam pembelajaran daring pada masa Pandemi Covid-19, sehingga dengan adanya penelitian ini dapat digunakan sebagai bahan refrensi untuk mengkaji pelaksanaan pembelajaran daring. Selain itu, penelitian ini memiliki kelebihan jika dibadingkan dengan penelitian lainnya, dimana karena masih minimnya peneliti yang melakukan penelitian tentang pola interaksi guru dan orangtua dalam pembelajaran dari maka hasil penelitian ini dapat digunakan sebagai bahan kajian atau tambahan refrensi terkait interaksi antara guru dan orangtua peserta didik dalam pembelajaran daring ataupun variabel lainnya di dalam pelaksanaan pembelajaran daring di masa pandemi covid-19 ini. Temuan-temuan yang didapatkan dari penelitian ini memberikan implikasi yakni temuan dalam penelitian ini dapat digunakan sebagai kajian maupun tambahan informasi untuk pengembangan penelitian yang berkaitan dengan survey pola interaksi guru dan orang tua dalam penerapan pembelajaran secra daring. Selain itu, karena keterbatasan penelitian ini, yang hanya meneliti terkait pola interaksi guru dan orang tua dalam pembelajaran daring pada masa pandemi Covid-19, penulis merekomendasikan agar penelitian selanjutnya dapat mengkaji dengan variabel yang lebih luas dan juga feedbacknya terhadap kegiatan pembelajaran daring.

\section{SIMPULAN}

Berdasarkan hasil temuan dan pembahasan maka dapat disimpulkan bahwa pola interaksi guru dan orangtua dalam penerapan pembelajaran daring di TK Kecamatan Blahbatuh sudah dilaksanakan dengan cukup baik. Terlihat dari sudah adanya kerjasama dan komunikasi yang baik antara guru dengan orangtua mulai dari perencanaan pembelajaran sampai dengan pelaksanaan pembelajaran daring di masa pandemi Covid-19 ini, guru dan orangtua saling bertukar informasi terkait dengan perkembangan anak dalam melaksanakan pembelajaran daring.

\section{DAFTAR RUJUKAN}

Adha, M. R. A., Murdiyanto, E., \& Hamidah, S. (2019). Perubahan Interaksi Masyarakat Melalui Kontak Sosial dan Komunikasi Sosial di Desa Wisata Singosaren Wukirsari Kecamatan Imogiri Kabupaten Bantul. Jurnal Dinamika Sosial Ekonomi, 20(2), 160-172. https://doi.org/10.31315/jdse.v20i2.3490.

Aji, R. H. S. (2020). Dampak Covid-19 pada Pendidikan di Indonesia: Sekolah, Keterampilan, dan Proses Pembelajaran. SALAM: Jurnal Sosial Dan Budaya Syar-I, 7(5). https://doi.org/10.15408/sjsbs.v7i5.15314.

Angus, D. C. (2020). Optimizing the Trade-off between Learning and Doing in a Pandemic. JAMA - Journal of the American Medical Association, 323(19), 1895-1896. https://doi.org/10.1001/jama.2020.4984.

Ansari, A., \& Purtell, K. M. (2017). Activity settings in full-day kindergarten classrooms and children's early learning. Early Childhood Research Quarterly, 38, 23-32. https://doi.org/10.1016/j.ecresq.2016.09.003.

Anwas, O. M. (2011). Pembudayaan Teknologi Informasi dan Komunikasi di Sekolah. Jurnal Teknodik, 15(1), 75-83. http://dx.doi.org/10.32550/teknodik.v0i0.90.

Apriyanti, C. (2021). The Role of Parents in Learning During The Covid-19 Outbreak. International Journal of Education \& Curriculum Application, 4(1), 18-25. https://doi.org/10.31764/ijeca.v4i1.4237.

Ardiawan, I. K. N., \& Heriawan, I. G. T. (2020). Pentingnya Komunikasi Guru dan Orangtua Serta Strategi PMP dalam Mendukung Pembelajaran Daring. DANAPATI: Jurnal Komunikasi, 1(1), 95-105. http://jurnal.ekadanta.org/index.php/danapati/article/view/37/10.

Arifa, F. N. (2020). Tantangan Pelaksanaan Kebijakan Belajar Dari Rumah Dalam Masa Darurat Covid-19. Info Singkat;Kajian Singkat Terhadap Isu Aktual Dan Strategis, 12(7), 13-18. http://berkas.dpr.go.id/puslit/files/info_singkat/Info Singkat-XII-7-I-P3DI-April-2020-1953.pdf.

Astini, N. K. S. (2020). Pemanfaatan Teknologi Informasi dalam Pembelajaran Tingkat Sekolah Dasar pada Masa Pandemi Covid-19. Jurnal LAMPUHYANG, 11(2), 13-25. https://doi.org/10.47730/jurnallampuhyang.v11i2.194.

Astuti, A. dewi, \& Presiadi, D. (2020). Efektivitas Penggunaan Media Belajar Dengan Sistem Daring Ditengah Pandemi Covid-19. N: Prosiding Web-Seminar Nasional (Webinar), 129-135.

Ayuni, D., Marini, T., Fauziddin, M., \& Pahrul, Y. (2020). Kesiapan Guru TK Menghadapi Pembelajaran Daring Masa Pandemi Covid-19. Jurnal Obsesi : Jurnal Pendidikan Anak Usia Dini, 5(1), 414-421. https://doi.org/10.31004/obsesi.v5i1.579.

Cahyati, N., \& Kusumah, R. (2020). Peran Orang Tua Dalam Menerapkan Pembelajaran Di Rumah Saat Pandemi Covid 19. Jurnal Golden Age, 4(1), 4-6. https://doi.org/10.29408/jga.v4i01.2203. 
Chusna, P. A., \& Utami, A. D. M. (2020). Dampak Pandemi Covid-19 Terhadap Peran Orang Tua Dan Guru Dalam Meningkatkan Kualitas Pembelajaran Daring Anak Usia Sekolah Dasar. PREMIERE : Journal of Islamic Elementary Education, 2(1), 11-30. https://doi.org/10.51675/jp.v2i1.84.

Dewi, W. A. F. (2020). Dampak COVID-19 terhadap Implementasi Pembelajaran Daring di Sekolah Dasar. Edukatif: Jurnal Ilmu Pendidikan, 2(1), 55-61. https://doi.org/10.31004/edukatif.v2i1.89.

Diana, R., Darmawan, I. P. A., \& Simamora, E. S. B. (2021). Kerjasama Orang Tua dan Guru dalam Pembelajaran PAUD di Masa Pandemi COVID-19. Vox Dei: Jurnal Teologi Dan Pastoral, 2(1), 1-16. https://doi.org/10.46408/vxd.v2i1.42.

Fauzi, I., \& Sastra Khusuma, I. H. (2020). Teachers' Elementary School in Online Learning of COVID-19 Pandemic Conditions. Jurnal Iqra': Kajian Ilmu Pendidikan, 5(1), 58-70. https://doi.org/10.25217/ji.v5i1.914.

Fitriyani, Y., Fauzi, I., \& Sari, M. Z. (2020). Motivasi Belajar Mahasiswa Pada Pembelajaran Daring Selama Pandemik Covid-19. Jurnal Kependidikan, 6(2), 165-175. https://doi.org/10.33394/jk.v6i2.2654.

Handarini, O. I., \& Wulandari, S. S. (2020). Pembelajaran Daring Sebagai Upaya Study From Home (SFH) Selama Pandemi Covid 19. Jurnal Pendidikan Administrasi Perkantoran (JPAP) Volume, 8(3), 496503. https://journal.unesa.ac.id/index.php/jpap/article/view/8503/4094.

Hasanah, H., Morjohan, \& Daharnis. (2020). Contribution of Self-esteem and Parents Social Support to Students Academic Resilience in Online Learning. International Journal of Applied Counseling and Social Sciences, 2(1), 73-79. https://doi.org/10.24036/005400ijaccs.

Irwanto, M. S. H. (2020). Implementasi Kolaborasi Orang Tua dan Guru Dalam Pelaksanaan Pembelajaran Daring pada PAUD. JIEES: Journal of Islamic Education at Elementary School, 1(1), 17-24. https://doi.org/10.47400/jiees.v1i1.8.

Kartini, Y. (2020). Kerjasama Orang Tua dan Guru dalam Penyelenggaraan Pembelajaran Online sebagai upaya pencegahan virus corona di MI Muhammadiyah Pasirmuncang. QALAM: Jurnal Pendidikan Islam, 1(1), 77-91. http://ejournal.stais.ac.id/index.php/qlm/article/view/22/11.

Khadijah, K., \& Gusman, M. (2020). Pola Kerja Sama Guru Dan Orangtua Mengelola Bermain Aud Selama Masa Pandemi Covid-19. Kumara Cendekia, 8(2), 154. https://doi.org/10.20961/kc.v8i2.41871.

Khadilkar, H., Ganu, T., \& Seetharam, D. P. (2020). Optimising Lockdown Policies for Epidemic Control using Reinforcement Learning. Transactions of the Indian National Academy of Engineering, 5(2), 129132. https://doi.org/10.1007/s41403-020-00129-3.

Koten, M. vivianti bare, \& Iswayudi, D. (2019). Pola Interaksi Mahasiswa Etnis Timur Dan Etnis Jawa Untuk Meningkatkan Kerukunan Bermasyarakat Di Kampus. Prosiding Seminar Nasional Pendidikan Dan Pembelajaran Bagi Guru Dan Dosen, 3, 272-278. https://conference.unikama.ac.id/artikel/index.php/fip/article/view/207/177.

Kristina, M., Sari, R. N., \& Nagara, E. S. (2020). Model Pelaksanaan Pembelajaran Daring Pada Masa Pandemi Covid 19 Di Provinsi Lampung. Idaarah: Jurnal Manajemen Pendidikan, 4(2), 200-209. https://doi.org/10.24252/idaarah.v4i2.16945.

Kurniasih, N. (2020). Pola interaksi dan implikatur percakapan dalam pemebelajaran bahasa indonesia di grup whatsapp pada masa pandemi covid-19 kelas X TKRO 1 SMK Negeri 2 Kendal tahun pelajaran 2019/2020. Jurnal Pendidikan Bahasa Dan Sastra Indonesia, 8(2), 1-22. http://journal.upgris.ac.id/index.php/sasindo/article/view/6821.

Larimore, R. A. (2020). Preschool Science Education: A Vision for the Future. Early Childhood Education Journal, 48(6), 703-714. https://doi.org/10.1007/s10643-020-01033-9.

Lilawati, A. (2020). Peran Orang Tua dalam Mendukung Kegiatan Pembelajaran di Rumah pada Masa Pandemi. Jurnal Obsesi : Jurnal Pendidikan Anak Usia Dini, 5(1), 549. https://doi.org/10.31004/obsesi.v5i1.630.

Limbong, M., Ali, S., Rabbani, R., \& Syafitri, E. (2020). Pola Interaksi Guru dan Orangtua dalam Mengendalikan Emosional Siswa Selama Pembelajaran Daring di MTS Islamiyah Medan. THORIQOTUNA: Jurnal Pendidikan Islam, 3(1), 44-55. https://doi.org/ 10.47971/tjpi.v3i1.226.

Lubis, R. R., \& Nasution, M. H. (2017). Implementasi Pendidikan Karakter di Madrasah Ibtidaiyah. JIP: Jurnal Ilmiah PGMI, 3(1), 15-32. https://doi.org/10.19109/jip.v3i1.1375.

Mahdi, N. I., Roza, M. Y., Ginting, E. br, \& Lestari, W. (2020). Pola Interaksi Guru dan Orang Tua dalam Meningkatkan Keterampilan Motorik AUD Selama Masa Pandemi Covid 19 di TK Al Ikhlas. Hikmah, 17(2), 86-98. http://e-jurnal.staisumatera-medan.ac.id/index.php/hikmah/article/view/82.

Musyarrofah, S., Hanief, M., \& Anggraheni, I. (2021). Kerjasama Guru Dan Orang Tua Dalam Pembelajaran Daring Di Roudlotul Athfal Muslimat NU 15, Sukun Kota Malang. Dewantara: Jurnal Ilmiah $\begin{array}{lllll}\text { Pendidikan Islam Anak Usia } & \text { Dini, } & \text { 3(1), }\end{array}$ http://riset.unisma.ac.id/index.php/jd/article/view/11996/9283.

Nurasiah, \& Solehuddin, M. (2021). The Role of Teachers and Parents of Online Learning in Primary School 
During the Covid-19 Pandemic Era. International Conference on Elementary Education, 3(November), 139-144. http://proceedings.upi.edu/index.php/icee/article/view/1455.

Putro, K. Z., Amri, M. A., Wulandari, N., \& Kurniawan, D. (2020). Pola Interaksi Anak Dan Orangtua Selama Kebijakan Pembelajaran Di Rumah. Fitrah: Jurnal of Islamic Education, 1(1), 124-140. http://jurnal.staisumatera-medan.ac.id/index.php/fitrah/article/view/12.

Rasmitadila, Aliyyah, R. R., Rachmadtullah, R., Samsudin, A., Syaodih, E., Nurtanto, M., \& Tambunan, A. R. S. (2020). The perceptions of primary school teachers of online learning during the covid-19 pandemic period: A case study in Indonesia. Journal of Ethnic and Cultural Studies, 7(2), 90-109. https://doi.org/10.29333/ejecs/388.

Rihatno, T. (2017). Hubungan Kepemimpinan dan Komunikasi Interpersonal dengan Kerjasama Tim Mahasiswa Anggota Klub Olahraga Prestasi Softball Universitas Negeri Jakarta. Jurnal Segar, 6(1), 44-60. https://doi.org/10.21009/segar.0601.05.

Risdoyok, \& Aprison, W. (2021). Kerjasama Guru PAI dan Orang Tua dalam Menghadapi Pembelajaran selama Covid-19. Edukatif : Jurnal Ilmu Pendidikan Research \& Learning in Education, 3(5), 23192335. https://doi.org/10.31004/edukatif.v3i5.819.

Suryaman, M., Cahyono, Y., Muliansyah, D., Bustani, O., Suryani, P., Fahlevi, M., Pramono, R., Purwanto, A., Purba, J. T., Munthe, A. P., Juliana, \& Harimurti, S. M. (2020). COVID-19 Pandemic and Home Online Learning System: Does It Affect The Quality of Pharmacy School Learning? Systematic Reviews in Pharmacy, 11(8), 524-530. https://doi.org/10.31838/srp.2020.8.74.

Sutarto, S., Sari, D. P., \& Fathurrochman, I. (2020). Teacher strategies in online learning to increase students' interest in learning during COVID-19 pandemic. Jurnal Konseling Dan Pendidikan, 8(3), 129-137. https://doi.org/10.29210/147800.

Syarifudin, A. S. (2020). Impelementasi Pembelajaran Daring Untuk Meningkatkan Mutu Pendidikan Sebagai Dampak Diterapkannya Social Distancing. Jurnal Pendidikan Bahasa Dan Sastra Indonesia Metalingua, 5(1), 31-34. https://doi.org/10.21107/metalingua.v5i1.7072.

Wardati, L., Husna, N., Khairunisa, A., \& Lubis, H. (2020). Pola Kerjasama Guru Dan Orang Tua pada Masa Pandemi Covid 19 di RA Masjid Agung Medan Polonia. AL-Ulum Jurnal Pendidikan Islam, 1(2), 165183. https://doi.org/10.30596/al-ulum.v.

Winarti, A. (2020). Implementasi Parenting pada Pendidikan Anak Usia Dini di Masa Pandemi COVID 19. Jurnal Pendidikan Pembelajaran Pemberdayaan Masyarakat, 2(2), 131-145. https://doi.org/ 10.37577/jp3m.v2i2.272. 